\title{
Enhancing Student's Writing Ability in Paragraph Writing Through an Outline Strategy at Primary Level
}

\author{
Hassan Ramzan ${ }^{*}$, Muhammad Hafeez ${ }^{2 *}$ \\ 1,2 Allama Iqbal Open University, Islamabad, Pakistan \\ *Corresponding author: hassanramzanchishti@gmail.com ${ }^{1}$, mh9589041@gmail.com²
}

\section{Abstrak}

Diantara keterampilan berbahasa, menulis dianggap sebagai keterampilan yang paling menantang dan berbelit-belit dibandingkan dengan keterampilan lainnya. Tujuan utama dari penelitian ini adalah untuk menganalisis peningkatan keterampilan menulis siswa dalam menulis paragraf melalui strategi outline. Partisipan dalam penelitian ini adalah 15 siswa kelas V. Partisipan tersebut dipilih melalui teknik random sampling. Data yang diperoleh dianalisis dalam persentase. Pre-Test dan Post-Test digunakan sebagai instrumen dalam penelitian ini. Dalam Pre-Test dan Post-Test item yang dibutuhkan seperti penulisan judul paragraf, tata bahasa, ejaan dan total kalimat (panjang) paragraf adalah sama. Menurut temuan, dalam Pre-Test siswa menulis paragraf adalah 20,00\%, 26,66\%, 20,00\%, 26,66\% (Baik), 46,66\%, 20,00\%, $33,33 \%, 33,33 \%$ (Rata-rata), 33,33\%, 53,33\%, 46,66\% , 40,00\% (Lemah) dalam judul penulisan paragraf, penggunaan tata bahasa yang tepat, ejaan yang benar dan jumlah kalimat (panjang) paragraf, masing-masing. Setelah Pre-Test, instruktur mengajarkan peserta tentang menulis paragraf melalui strategi outline selama 4 minggu dan kemudian dilakukan Post-Test. Dalam tes ini, peserta menulis paragraf melalui strategi outline adalah 46,66\%, 53,33\%, 60,00\%, 53,33\% (Baik), 40,00\%, 26,66\%, 33,33\%, 40,00\% (Rata-rata), 13,33\%, 20,00\%, 6,66\% , 6,66\% (Lemah) dalam judul penulisan paragraf, penggunaan tata bahasa yang tepat, ejaan yang benar dan jumlah kalimat (panjang) paragraf, masing-masing. Penelitian berbasis tindakan ini menunjukkan bahwa strategi outline dapat meningkatkan keterampilan menulis siswa.

Kata kunci: Menulis, Paragraf, Strategi

\section{Abstract}

Among language skills, writing is considered the most challenging and complicated skill compared to other skills. The main objective of this research is to analyze the improvement of students' writing skills in writing paragraphs through the outline strategy. The participants in this study were 15 fifth grade students. The participants were selected through random sampling technique. The data obtained were analyzed in percentage. Pre-Test and Post-Test were used as instruments in this study. In the Pre-Test and Post-Test the required items such as writing paragraph titles, grammar, spelling and total sentences (length) of paragraphs are the same. According to the findings, in the Pre-Test the students writing paragraphs were $20.00 \%$, 26.66\%, 20.00\%, 26.66\% (Good), 46.66\%, 20.00\%, 33.33\%, 33 ,33\% (Average), 33.33\%, 53.33\%, 46.66\% , 40.00\% (Weak) in paragraph headings, use of proper grammar, correct spelling and number of sentences (length ) paragraphs, respectively. After the Pre-Test, the instructor taught the participants about writing paragraphs through an outline strategy for 4 weeks and then conducted a Post-Test. In this test, participants in writing paragraphs through the outline strategy were $46.66 \%, 53.33 \%, 60.00 \%, 53.33 \%$ (Good), 40.00\%, 26.66\%, 33.33\%, 40 0.00\% (Average), $13.33 \%, 20.00 \%, 6.66 \%, 6.66 \%$ (Weak) in paragraph headings, use of proper grammar, correct spelling and number of sentences (length ) paragraphs, respectively. This action-based research shows that the outline strategy can improve students' writing skills.

Keywords: Writing, Paragraphs, Strategy

\begin{tabular}{lll}
\hline History: & & Publisher: Undiksha Press \\
Received & : June 19, 2021 & Licensed: This work is licensed under \\
Revised & : June 21,2021 & a Creative Commons Attribution 3.0 License \\
Accepted & : July 14, 2021 &
\end{tabular}

\section{Introduction}

Learning is an important element of society and play a vital role in the development of a nation (H. Pratama et al., 2020; Spencer, 2021; Van Woezik et al., 2019). The success of learning can be measured based on the achievement of competencies that have been determined at the beginning of learning activities (Dashtestani, 2013; Saripudin et al., 2018). So that all parties who actively participate in the learning process, namely students and teachers, already know the direction of learning. Therefore, both parties need to work 
together to support each other to enable the achievement of the desired competencies and to carry out teaching and learning activities. Steps are needed to achieve the goals set (Mpungose, 2021; Silva et al., 2018). Thus, teacher and student awareness of the goals that must be achieved in the learning process is an absolute and non-negotiable requirement, so that in the process, teachers and students lead to the same goal (Taylor et al., 2017; Yudhiantara \& Saehu, 2017).

English as a language learning is the most crucial challenge for the non-native English learners (Hill et al., 2020; Skarpaas \& Hellekjær, 2021). The ability to speak English is one of the essential skills for students because English has become a universal language used in technology, education, politics, commerce and is the most frequently used communication tool globally (Karimi \& Sanavi, 2014; Liu \& Hu, 2021). Language is most essential source of communication employed to share ideas and information between two or more people in the execution of their daily tasks (Fu et al., 2019; Naghdipour, 2021). It is the main way due to which humans have the skills to convey messages and contact with each other (Karimi \& Sanavi, 2014; Liu \& Hu, 2021).

In studying language, there are four skills such as listening, speaking, reading and writing that must be commanded (Muhammed, 2014; Sadeghi \& Sadeghi, 2012). Among language skills, writing is regarded as most challenging and convoluted skill as compared to other skills (reading, listening and speaking) (Hill et al., 2020; Riazi, 2016). It is easier to understand meaning by reading and listening as compared to form meaning by writing because writing skill needs a lot of struggles (Amiryousefi \& Tavakoli, 2011; Naghdipour, 2021). Initially most of the linguists perhaps recommend outline technique for writing something. For writing a good outline provide structures for writing. The outline not only comprises on headings, but also gives information about sub-section heading or specific ideas. It also forms notes regarding each section as well as any phrases or sentences we could employ in the process of writing (Setyowati \& Sukmawan, 2016; Yusuf et al., 2019).

Writing is one of the skills which can be easily acquired by practicing (Kim, 2017; Nihal, 2017). writing is just like an art, which could be strengthened only by practice. Commanding on the passive voice form is not the story ending (Bipinchandra et al., 2014; Ling, 2017). Learner should experience themselves by using passive voice. Teaching is motivating learners for practicing the language skills. The learning is experience of an individual by its own (personal) and it requires active participation of an individual (Budiaman et al., 2021; Sukardi et al., 2020). However, psychologists stated that learners not acquire knowledge just like sponge gets in water (Sun \& Wang, 2020). For enhancing writing skill in learners, it is most essential that teacher must be competent as well as teaching methodology must be diversified (Abrams \& Byrd, 2016; Smart, 2019). Previous research also stated that writing is critical to be mastered by students in English (Abrams \& Byrd, 2016; Mayarnimar \& Taufina, 2017). The objective of current study was to find the improvement in students writing skills in writing paragraph through an outline strategy.

Several relevant studies supported this research. Firstly, the study that the picture and picture learning model can improve student learning activities in arts and culture subjects (Rosmalem, 2017). Second, the thematic learning in the perspective of Revised Bloom's Taxonomy could make the learning process more meaningful (Ardiani et al., 2013). Third, the development of HOTS-based teaching materials could improve problem-solving abilities in mathematics subjects (Anisah \& Lastuti, 2018; Hamdi et al., 2018; G. S. Pratama \& Retnawati, 2018). The purpose of this study was to analyze the effectiveness of learning activities based on Revised Bloom's Taxonomy on the problem-solving abilities of fourthgrade elementary school students in Cluster IV, Buleleng District, Buleleng Regency for the 2020/2021 Academic Year. 


\section{Methods}

A descriptive case study research method was used in this research to evaluate the grade five students paragraph writing through an outline strategy by using Pre-Test and PostTest. In this research, population comprised of students (grade five) of five government primary schools located in D. G. Khan city. In each school, there were thirty students of grade five. It was not feasible to obtain data from all the participants or members of a population. Thus, 3 of participants from each school were chosen for data collection. The participants of the research were grade five students. By using simple random sampling technique, 15 participants were selected from the population.

Pre-Test and Post-Test instruments were used for collecting in this research. The PreTest question was only about writing paragraph on topic "My Self" of maximum five sentences (short paragraph). The purpose was to check whether the students were able to know how to write correct sentences and then to follow the correct technique of writing paragraphs. The participants were allowed only 20 minutes to answer the test. Then, Pre-Test of all the participants were marked. Pre-Test mainly focused on required items like title, grammar, spelling and total sentences in paragraph. Before conducting Post-Test, all participants were taught about writing paragraph through an outline strategy for a period of 4 weeks. The Post-Test question was about writing paragraph on "Picnic". Participants were allowed only 20 minutes to answer the test. After Post-Test, such test of all participants was marked by focusing the same required items as in Pre-Test.

The data was recorded from all the participants by using test technique. The pre-Test was administered to 15 participants (sample) to gather the baseline or initial data. After collecting the initial data, English instructor taught their participants about writing paragraph by using outline strategy for a period of four weeks. Then, a Post-Test was taken from 15 participants (sample) to

check whether the intervention favorable for the students to gain good results or not. After gathering the data through Pre-Test and Post-Test, recorded data was analyzed by using quantitative data analyzing method. In this way, score of participants from both tests were counted into percentages. Finally on the basis of observed data analysis, researcher summarized the findings and draw conclusion.

\section{Results and Discussion Results}

In both Pre-Test and Post-Test, required items like paragraph title, grammar, spelling and total sentence (length) of paragraph were similar but in Pre-Test paragraph writing through an outline was not employed. While in Post-Test, participants wrote paragraph through an outline strategy.

Table 1. For Paragraph Title Writing in Pre-Test

\begin{tabular}{ccc}
\hline Ranking & No. of Participants & Percentage \\
\hline Good & 3 & $20 \%$ \\
Average & 7 & $46.66 \%$ \\
Weak & 5 & $33.33 \%$ \\
\hline
\end{tabular}

Table 1 showed that out of 15 participants, only 3 participants (20\%) ranked good, 7 participants regarded as average $(46.66 \%)$ while 5 participants $(33.33 \%)$ considered as weak in Pre-Test for paragraph writing title. Based on the results of data analysis, it was clear that most of the participants (53.33\%) were weak, 3 participants as average, 4 participants were 
good in the use of grammar in Pre-Test. The represented $20 \%$ participants were good in correct spelling in Pre-Test while $33.33 \%$ and $46.66 \%$ participants ranked as average and weak, respectively.The various ranking of participants in case of total sentences in paragraph such as $26.66 \%$ participants were good, $33.33 \%$ average and $40 \%$ weak. The results of the post-test analysis are presented in table 2 .

Table 2. For Paragraph Title Writing in Post-Test

\begin{tabular}{ccc}
\hline Ranking & No. of Participants & Percentage \\
\hline Good & 7 & $46.66 \%$ \\
Average & 6 & $40 \%$ \\
Weak & 2 & $13.33 \%$ \\
\hline
\end{tabular}

Table 2 showed that $46.66 \%$ participants were good in Post-Test for paragraph title writing. Forty percent of the participants considered as average. Only 2 participants ranked as weak in this required item. Based on the results of data analysis, that most of the participants (53.33\%) were good, 4 participants as average, 3 participants were weak in the use of grammar in Post-Test. The represented $60 \%$ participants were good in correct spelling in Post-Test while $33.33 \%$ and $6.66 \%$ participants ranked as average and weak, respectively. The various ranking of participants in case of total sentences in paragraph such as $53.33 \%$ participants were good, $40 \%$ average and $6.66 \%$ weak. The results of the participants were improved as compared to Pre-Test. This was due to the outline strategy because in Post-Test this strategy was used.

\section{Discussion}

Language is very important tool of communication used to communicate between two or more people in carrying out their daily activities and had main role to make people had mutual understanding (Al-Malki \& Zahid Javid, 2018; Saddhono et al., 2019). By using language, we could communicate with others. In learning language, there were four skills that should be mastered, they were: speaking, listening, reading and writing (Curry et al., 2017; Karimi \& Sanavi, 2014; Sharif Matthews \& López, 2019). Writing is one of the four language skill. It is not a natural skill because one could not acquire this ability automatically and easily (Hill et al., 2020; Riazi, 2016). To acquire it, the students should get sufficient writing practices. These practices are supposed to stimulate the student's skill in writing and expressing thoughts in a good passage (Fu et al., 2019; Vassilaki, 2017). Without practicing, it is impossible to write well and effectively. There are many kinds of writing. One of them is writing paragraph.

Paragraph is the basic unit of organization in writing that consisted of more than two sentences (Flores, 2021; Mayarnimar \& Taufina, 2017). A paragraph has three major structural parts: a topic sentence, supporting sentence, and concluding sentences. In writing, students feel hard to develop their ideas, knowledge, or their ability (Karaca \& Uysal, 2021; Llosa \& Malone, 2017). Some considerations in writing an academic text. The first is that writers should consider the vocabulary used in their writing. He suggests several guidelines for vocabulary used: (1) use vocabulary accurately, (2) avoid using idiomatic, instead use standard English, (3) be as precise as possible, (4) use tentative language for conclusions, (5) avoid adverbs that show personal attitude, (6) do not use contract verb forms, (7) passive voice may not be over-used, (8) avoid using the word like to introduce examples, the word thing, instead use factor, aspect or issue, the word lots of and little or big, instead use a significant, small or large, (9) do not use question forms, (10) avoid numbering sections, (11) avoid using etc or and so on, and (12) avoid using phrasal verbs (Masrur et al., 2020; Staples et al., 2013; Su et al., 2021). 


\section{Conclusion}

The findings of the study indicated that the use of outline strategy improves students writing skill especially in descriptive paragraph writing at primary level. Outline enhances students writing skill, learners feel easy to design their writing, organized idea and constructed their sentences into a good paragraph. Outlining strategy is a really beneficial for both teacher and learner which make the students more active in writing especially in writing paragraph ability.

\section{References}

Abrams, Z. I., \& Byrd, D. R. (2016). The effects of pre-task planning on L2 writing: Mindmapping and chronological sequencing in a 1st-year German class. System, 63. https://doi.org/10.1016/j.system.2016.08.011

Al-Malki, E. A., \& Zahid Javid, C. (2018). Identification of Language Learning Beliefs Among Saudi EFL Learners. SSRN Electronic Journal, 9(4). https://doi.org/10.24093/awej/vol9no4.13

Amiryousefi, M., \& Tavakoli, M. (2011). The Relationship between Test Anxiety, Motivation and MI and the TOEFL iBT Reading, Listening and Writing Scores. Procedia - Social and Behavioral Sciences, 15. https://doi.org/10.1016/j.sbspro.2011.03.075

Anisah, \& Lastuti, S. (2018). Pengembangan Bahan Ajar berbasis HOTS untuk Meningkatkan Kemampuan Pemecahan Masalah Matematis Mahasiswa. Kreano: Jurnal Matematika Kreatif-Inovatif, 9(2), 191-197. https://doi.org/10.15294/kreano.v9i2.16341

Ardiani, N. F. W., Guna, N. A., \& Novitasari, R. (2013). Pembelajaran Tematik Dan Bermakna Dalam Perspektif Revisi Taksonomi Bloom. Satya Widya, 29(2), 93-107. https://doi.org/10.24246/j.sw.2013.v29.i2.p93-107

Bipinchandra, J. S. a/p, Shah, P. M., Puteh, S. N., Din, R., Rahamat, R., \& Aziz, J. A. (2014). User Needs Analysis in Learning Argumentative Writing Via Mobile Platform. Procedia - Social and Behavioral Sciences, 118. https://doi.org/10.1016/j.sbspro.2014.02.027

Budiaman, B., Komarudin, K., Nuruddin, N., \& Kustandi, C. (2021). Learning Design on Social Studies Through Digital Book in Senior High School. International Journal of $\begin{array}{llll}\text { Interactive } & \text { Mobile } & \text { Technologies } & \text { (IJIM), }\end{array}$ https://doi.org/10.3991/ijim.v15i09.18435

Curry, N., Mynard, J., Noguchi, J., \& Watkins, S. (2017). Evaluating a self-directed language learning course in a Japanese university. International Journal of Self-Directed Learning, 14(1), 17-36.

Dashtestani, R. (2013). Implementing mobile-assisted language learning (MALL) in an EFL context: Iranian EFL teachers' perspectives on challenges and affordances. The JALT CALL Journal, 9(2), 149-168. https://doi.org/10.29140/jaltcall.v9n2.153

Flores, J. A. A. (2021). The semiotics of writing: How adult L2 learners with emergent literacy make meaning in assessment texts through writing. Journal of Second Language Writing, 51. https://doi.org/10.1016/j.jslw.2021.100793

Fu, Q.-K., Lin, C.-J., Hwang, G.-J., \& Zhang, L. (2019). Impacts of a mind mapping-based contextual gaming approach on EFL students' writing performance, learning perceptions and generative uses in an English course. Computers \& Education, 137. https://doi.org/10.1016/j.compedu.2019.04.005

Hamdi, S., Suganda, I. A., \& Hayati, N. (2018). Developing higher-order thinking skill (HOTS) test instrument using Lombok local cultures as contexts for junior secondary 
school mathematics. Research and Evaluation in Education, 4(2), 126-135. https://doi.org/10.21831/reid.v4i2.22089

Hill, C., Khoo, S., \& Hsieh, Y.-C. (2020). An investigation into the learning transfer of English for specific Academic Purposes (ESAP) writing skills of students in Singapore. Journal of English for Academic Purposes, 46. https://doi.org/10.1016/j.jeap.2020.100908

Karaca, M., \& Uysal, H. H. (2021). The development and validation of an inventory on English writing teacher beliefs. Assessing Writing, 47. https://doi.org/10.1016/j.asw.2020.100507

Karimi, P., \& Sanavi, R. V. (2014). Analyzing English Language Learning Needs among Students in Aviation Training Program. Procedia - Social and Behavioral Sciences, 98. https://doi.org/10.1016/j.sbspro.2014.03.491

Kim, E.-Y. J. (2017). The TOEFL iBT writing: Korean students' perceptions of the TOEFL iBT writing test. Assessing Writing, 33. https://doi.org/10.1016/j.asw.2017.02.001

Ling, G. (2017). Are TOEFL iBT® writing test scores related to keyboard type? A survey of keyboard-related practices at testing centers. Assessing Writing, 31. https://doi.org/10.1016/j.asw.2016.04.001

Liu, Y., \& Hu, G. (2021). Mapping the field of English for specific purposes (1980-2018): A co-citation analysis. English for Specific Purposes, 61. https://doi.org/10.1016/j.esp.2020.10.003

Llosa, L., \& Malone, M. E. (2017). Student and instructor perceptions of writing tasks and performance on TOEFL iBT versus university writing courses. Assessing Writing, 34. https://doi.org/10.1016/j.asw.2017.09.004

Masrur, I., Irawati, E., \& Sulistyo, G. H. (2020). Integrating Writing Process with Quantum Learning Framework in English Language Teaching. Jurnal Pendidikan: Teori, Penelitian, Dan Pengembangan, 5(3). https://doi.org/10.17977/jptpp.v5i3.13262

Mayarnimar, \& Taufina. (2017). Validity Analysis of the VARK (Visual, Auditory, ReadWrite, and Kinesthetic) Model - Based Basic Reading and Writing Instructional Materials for the 1st Grade Students of Elementary School. Atlantis Press, 118, 870874. https://doi.org/10.2991/icset-17.2017.141

Mpungose, C. B. (2021). Lecturers' reflections on use of Zoom video conferencing technology for e-learning at a South African university in the context of coronavirus. African Identities. https://doi.org/10.1080/14725843.2021.1902268

Muhammed, A. A. (2014). The Impact of Mobiles on Language Learning on the Part of English Foreign Language (EFL) University Students. Procedia - Social and Behavioral Sciences, 136. https://doi.org/10.1016/j.sbspro.2014.05.297

Naghdipour, B. (2021). English writing pedagogy at the crossroads: The case of Oman. Journal of Second Language Writing, 52. https://doi.org/10.1016/j.jslw.2021.100815

Nihal, G. Ö. Y. (2017). An action research on the development of self-regulated writing strategies of Turkish EFL students. Eurasian Journal of Applied Linguistics, 3(2). http://www.ejal.eu/

Pratama, G. S., \& Retnawati, H. (2018). Urgency of Higher Order Thinking Skills (HOTS) Content Analysis in Mathematics Textbook. Journal of Physics: Conference Series, 1097(1). https://doi.org/10.1088/1742-6596/1097/1/012147

Pratama, H., Azman, M. N. A., Gulzhaina K. Kassymova, \& Duisenbayeva, S. S. (2020). The Trend in Using Online Meeting Applications for Learning During the Period of Pandemic COVID-19: A Literature Review. Journal of Innovation in Educational and Cultural Research, 1(2), 58-68. https://doi.org/10.46843/jiecr.v1i2.15

Riazi, A. M. (2016). Comparing writing performance in TOEFL-iBT and academic assignments: An exploration of textual features. Assessing Writing, 28. 
https://doi.org/10.1016/j.asw.2016.02.001

Rosmalem. (2017). Peningkatan Aktivitas Belajar Siswa Dengan Model Pembelajaran Picture And Picture Pada Pelajaran Seni Budaya. Jurnal Handayani: Jurnal Kajian Pendidikan Pra Sekolah Dan Pendidikan Dasar, 6(2), 153-161. https://doi.org/10.24114/jh.v6i2.6529

Saddhono, K., Sudarsana, I. K., \& Iskandar, A. (2019). Implementation of Indonesian Language the learning Based on Information and Communication Technology in Improving Senior High School Students' Achievement in Surakarta. Journal of Physics: Conference Series, 1254(1). https://doi.org/10.1088/1742-6596/1254/1/012059

Sadeghi, A., \& Sadeghi, A. (2012). The relevance of Mastery Learning (ML) in Teaching of English (Case Study of the University of Guilan, Iran). Creative Education, 3(1). https://doi.org/10.4236/ce.2012.31007

Saripudin, E., Sari, I. J., \& Mukhtar, M. (2018). Using Macro Flash Animation Media on Motion Material to Improve Learning Achievement for Learning Science in Junior High School. Jurnal Penelitian Dan Pembelajaran IPA, 4(1), 68-75. https://doi.org/10.30870/jppi.v4i1.3316

Setyowati, L., \& Sukmawan, S. (2016). EFL Indonesian Students' Attitude toward Writing in

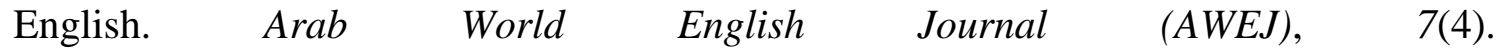
https://doi.org/10.24093/awej/vol7no4.24

Sharif Matthews, J., \& López, F. (2019). Speaking their language: The role of cultural content integration and heritage language for academic achievement among Latino children. Contemporary Educational Psychology, 57, 72-86. https://doi.org/10.1016/j.cedpsych.2018.01.005

Silva, A. B. Da, Bispo, A. C. K. de A., Rodriguez, D. G., \& Vasquez, F. I. F. (2018). Problem-based learning: A proposal for structuring PBL and its implications for learning among students in an undergraduate management degree program. REGE Revista de Gestão, 25(2), 160-177. https://doi.org/10.1108/REGE-03-2018-030

Skarpaas, K. G., \& Hellekjær, G. O. (2021). Vocational orientation - A supportive approach to teaching L2 English in upper secondary school vocational programmes. International Journal of Educational Research Open, 2(2). https://doi.org/10.1016/j.ijedro.2021.100064

Smart, J. (2019). Affordances of TOEFL writing tasks beyond university admissions. Assessing Writing, 41. https://doi.org/10.1016/j.asw.2019.06.006

Spencer, J. A. (2021). Integrating Service Learning into the RN to BSN Curriculum with the Application of QSEN Competencies. Journal of Professional Nursing, 25. https://doi.org/10.1016/j.profnurs.2021.08.007

Staples, S., Egbert, J., Biber, D., \& McClair, A. (2013). Formulaic sequences and EAP writing development: Lexical bundles in the TOEFL iBT writing section. Journal of English for Academic Purposes, 12(3). https://doi.org/10.1016/j.jeap.2013.05.002

Su, H., Zhang, Y., \& Lu, X. (2021). Applying local grammars to the diachronic investigation of discourse acts in academic writing: The case of exemplification in Linguistics research articles. English for Specific Purposes, 63. https://doi.org/10.1016/j.esp.2021.05.002

Sukardi, Mayefis, R., \& Usmeldi. (2020). Effectiveness of Mobile Learning Media on Computer Assembly at Vocational High School Effectiveness of Mobile Learning Media on Computer Assembly at Vocational High School. Journal of Physics: Conference Series, 1-6. https://doi.org/10.1088/1742-6596/1594/1/012012

Sun, T., \& Wang, C. (2020). College students' writing self-efficacy and writing selfregulated learning strategies in learning English as a foreign language. System, 90. https://doi.org/10.1016/j.system.2020.102221 
Taylor, A. T. S., Olofson, E. L., \& Novak, W. R. P. (2017). Enhancing student retention of prerequisite knowledge through pre-class activities and in-class reinforcement. Biochemistry and Molecular Biology Education, 45(2), 97-104. https://doi.org/10.1002/bmb.20992

Van Woezik, T., Reuzel, R., Koksma, J., \& Serpa, S. (2019). Exploring open space: A selfdirected learning approach for higher education. Cogent Education, 6(1), 1-22. https://doi.org/10.1080/2331186X.2019.1615766

Vassilaki, E. (2017). Reflective writing, reflecting on identities: The construction of writer identity in student teachers' reflections. Linguistics and Education, 42. https://doi.org/10.1016/j.linged.2017.08.001

Yudhiantara, R. A., \& Saehu, A. (2017). Mobile-Assisted Language Learning (MALL) in Indonesian Islamic Higher Education. IJELTAL (Indonesian Journal of English Language Teaching and Applied Linguistics), 2(1), 21-31. https://doi.org/10.21093/ijeltal.v2i1.52

Yusuf, Q., Jusoh, Z., \& Yusuf, Y. Q. (2019). Cooperative Learning Strategies to Enhance Writing Skills among Second Language Learners. International Journal of Instruction, 12(1). http://www.e-iji.net/ 